\title{
The Tax Burden of Financial Institutions under the Background of COVID-19
}

\author{
Viswanadha Raju \\ Graduate Researcher, MSc Post War/Disaster Reconstruction and Rehabilitation, Ankara Yildrim Beyazit University
}

\begin{abstract}
How has the outbreak and rapid spread of the COVID-19 pandemic impacted the financial institutions in developing countries? This paper seeks to examine how the pandemic and the resulting government response are having a burden on the financial sector. Existing studies and policy responses have focused on the epidemiology of the disease, how to curb the spread of, and the impact of the pandemic on the health systems, education, and urban informal settlements. There is little attention to the impact of the pandemic on financial institutions, especially in developing countries. The author observes that financial institutions in developing countries were already struggling to recover from a series of international, regional, and national crises before the pandemic and that some of the government response measures aimed at cushioning the population from the economic pinch during the pandemic are making the situation worse. These policies have overlooked the potential role financial institutions in the post-COVID 19 recovery and financial stability in the global south. The paper, therefore, adopts the case of Malawi to assess the impact of the pandemic on the financial sector, it then discusses the significance of the financial sector of economic stability, gaps in the government responses and concludes with policy recommendations that could benefit developing countries in maintaining healthy financial institutions amid the pandemic.
\end{abstract}

Keywords: COVID 19, Financial Institutions, Malawi, Developing Countries

\section{Introduction}

Within the last five decades, a zoonotic virus belonging to the larger coronavirus family has crossed from other species and infected humans three times. More recently has been the outbreak of 2019-nCoV, also known as COVID-19 first detected in Wuhan district of Hubei Province, China. The first infections are believed to have originated in a wet seafood market in the district. Although there were quick efforts to recognize the epidemiological and clinical aspects of the disease, its rapid spread from Wuhan to other parts of the world appears not to have been well managed. In less than six months since the disease was detected in December 2019, more than 185 counties have reported patients suffering from the disease. This can be attributed to the possible impacts of underestimating the human-to-human transmission potential of the virus in the early stages as well as the lack of full understanding of how the virus reacts in different environments, age groups, and individual lifestyle. What is clear, however, COVID-19 is showing similar characteristics $(75-80 \%)$ with previous pathogenic respiratory viruses such as the Middle East Respiratory Syndrome Coronavirus (MERS-CoV) and the Severe Acute Respiratory Syndrome Coronavirus (SARS-CoV) ${ }^{1}$.

The rapid spread of COVID-19, which is a severe respiratory disease, has resulted in an unprecedented crisis not only in public health but also socio-economic spheres of many societies in the world. The financial sector is considered as an essential entity for economic growth and alleviating poverty ${ }^{2}$. Access to financial services by lowincome households through remittances, small loans, insurance services, and savings could further lead to economic opportunities that build up assets and income levels of the people. Nonetheless, the global south, have lower access to financial institutions which are currently under threat from the on-going COVID-19 pandemic ${ }^{3}$. This paper seeks to examine the experience and offer policy recommendations for developing countries during the pandemic.

\section{COVID 19 and the crisis on financial institutions}

Financial institutions (FIs) are critical actors in sustaining a healthy financial environment yet, these entities are highly vulnerable during natural disasters. Apart from instances where the sector suffers from economic crises triggered by various socio-economic and political factors that can result into non-performing loans, there are other factors that can severely affect the sector, and these include natural disasters and pandemics. Health crises in the last century have affected national and regional economies, however the outbreak and rapid spread of COVID-19 has exposed different critical sectors such as health, economy, education, and trade to serious threat of collapse. With the COVID-19 still clutching the world and posing enormous bane on the economic, health, and social system, the financial sector has also not been spared. Estimates so far show that the virus could trim global economic growth by $3 \%$ to $6 \%$ in 2020 , with a halfway recuperation in 2021, assuming there is not a second wave ${ }^{4}$. Moreso, the direct and indirect consequences of the pandemic continue to negatively affectFIs globally. These institutions are particularly suffering from destabilizing effects of the disease and some of the government response measures. At the beginning of February, financial analysts were optimistic that the outbreak would ease in a short period of time. Their confidence was buoyed by the initial levelling of cases by countries in Asia ${ }^{5}$. Nevertheless, the initial sanguine began to subside due to the continuous increase and the geographical spread in the number of infectious cases. Immediately the World Health Organisation (WHO) declared the coronavirus disease as a pandemic, FIs anticipated significant losses in the financial sector ${ }^{6}$. Moreover, governments across the world began to implement several measures such as nation-wide lockdown, curfews, containment and other health safety protocols and etiquettes including social distancing to curb the further 
spread of the virus. Only critical businesses including some departments of financial institutions working in shifts and providing essential services continued to function. Most international flights were halted by a majority of the countries except for evacuation of citizens of various countries and those carrying important health supplies. Owing to that, several economists and financial analysts anticipated a record level of unemployment, increased inflation, low investments, reduced economic activities, and trade.

In response to the pandemic, actors within the financial sector, including FIs begun to implement new operational measures to consider the emerging health protocols. With these, operations in FIs significantly declined, the number of people who could get services also shrunk due to the social distancing and lockdown. Bank services have increasingly been automated by several FIs especially in advanced economies leading to unemployment in the sector ${ }^{7}$. Corporations are also postponing investment decisions and thereby leading to the unprofitability of the financial sector ${ }^{2}$.

Currently, most FIs are facing a liquidity crunch, with liquidity drying up in the money market and the substantial reduction in the cash-inflows. With liquidity drying up and FIs incessant support to financing and lending activities, some FIs are struggling to comply with the minimum liquidity requirement for Net Stable Funding Ratio (NSFR) and Liquidity Coverage Ratio (LCR) ${ }^{8}$. Owing to that, governments, more so in the developed countries, around the world have instituted relief measures during the global pandemic in order to reduce the stress on financial institutions. Interest rates for banks have been cut, the reserve requirements have been reduced and there has been the institutionalisation of lower longer or lower maturity on the discount window ${ }^{9}$. Jackson et al.2 also add that monetary authorities and central banks have adopted a wide spectrum of interim measures to address the potential economic pitfalls during the pandemic. These include countercyclical capital buffers in some cases, relaxed capital buffers, prudential measures, foreign exchange swaps, and asset purchases, announcing new financing and lending facilities, lowing reserve requirements and interest rates, among others $^{2}$

These extemporaneous measures have led to an enormous increase in capital held by large advanced economy banks, together with more stable sources of funding and liquid assets ${ }^{10}$. Even small FIs in emerging economies have started picking up after receiving stimulus from various central banks and governments in these economies but the stimulus packages are not sufficiently able to cushion these FIs due to other non-fiscal and monetary factors ${ }^{5}$. Also, in developed economies, consumers have sharply increased their savings as a form of involuntary saving, or limited spending opportunities, and concerns over loss of incomes or jobs, or precautionary saving and the course of their economies ${ }^{2}$.

While these initial stimulus may have eased some financial crisis, concerns have been raised by financial analysts on the range of risks that could present a threat to financial stability $^{11}$. A real or perceived shift in interventions from the central bank in the financial market could inimically impact investors' concept of risk and negatively affect economy recovery and asset markets ${ }^{2}$. Some have also questioned the sustainability of the continuous monetary stimulus received from the governments of emerging economies as public debt and health expenditure continues to increase ${ }^{9}$. The International Monetary Fund (IMF) cautioned that "among developing countries, high debt levels could become 'unmanageable' and test the resilience of banks in some countries"12.

The prolonged pandemic continues to plunge countries into recession, with countries experiencing contractions with per capita income in the largest fraction ${ }^{2}$. Developed economies are expected to shrink $7.5 \%$ with spill overs to the developing economies, emerging markets, and financial institutions ${ }^{2}$. It is also projected that firms might find it difficult to service loans taken from financial institutions, the heightened aversion of risk could also lead to galloping borrowing costs, and defaults and bankruptcies could lead to the financial meltdown of many countries ${ }^{13}$, especially in the global south. The financial aftermath from the pandemic raises the risk of economic recession, globally, with levels of unemployment not experienced since the Great Depression of the $1930 \mathrm{~s}^{2}$. World trade could likewise fall by $13 \%$ to $32 \%$, contingent upon the profundity and degree of the global economic downturn, demanding a particularly overwhelming financial cost on trade-dependent emerging and developing economies ${ }^{14}$. This is due to the disruptions in the smooth functioning of the global dollar market which has several implications on financial transactions and international trade ${ }^{2}$. For developing countries which rely on imported goods, such a decline in international trade will lead to shortages that can also lead to a sharp spike in prices.

The pandemic has also had devastating impact on the informal sector as crowded open-air markets and industries are closed. Similarly, raw materials needed to drive production in the informal economy has reduced as waste collection and recycling activities continue to be restricted. These negative impacts continue to affect the transport industry, food supply, street vending which in developing country not only employ a significant number of people but also support informal and formal financial institutions. For example, table banking among women in Africa's informal sectors where members of a group are able to save a small portion of their daily income in a group then once the money reaches a specific target it is deposited in a formal financial institution where members of the group are able to get loans. With the pandemic, such activities are disrupted.

As depicted in Figure 1, it shows how the COVID-19 recession has seen the steepest and fastest downgrades in consensus growth projections among all global recessions since 1990. In sum, the prolonged pandemic is expected to heavily impact inflation in the near term, economic activity, and employment which poses considerable risks to the financial sector over the medium term.

Consensus Forecasts of Global GDP 


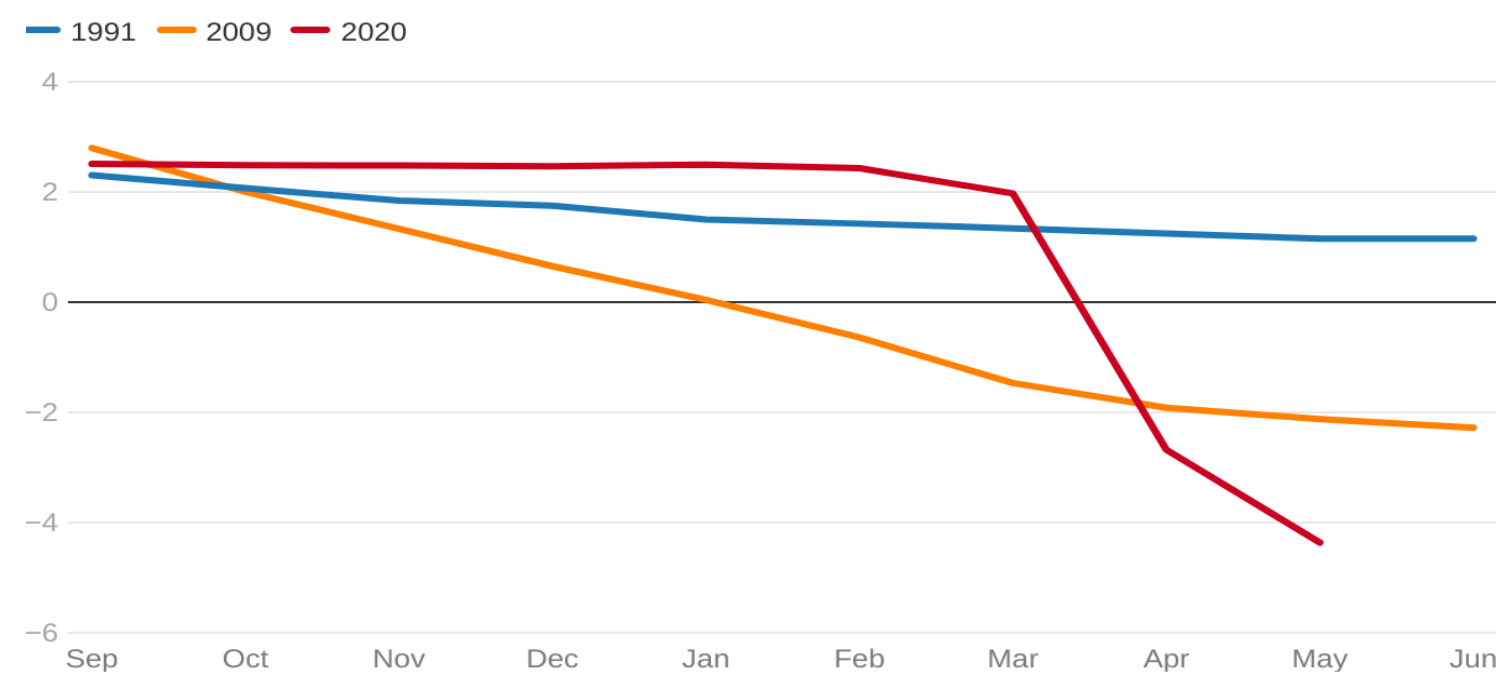

September to December shows forecasts made in the previous year, while January to June shows data for the zurrent year. Data for 1991 are for advanced economies only due to data availability.

Figure 1: Projection of COVID-19 recession since 1990

\section{Source: World Bank ${ }^{2}$}

Experience of COVID-19 in Malawi, government response and impact on financial institutions

The Malawian financial system consists of a nascent capital market, a growing microfinance industry, four development financial institutions, eight insurance companies, one leasing company, two discount houses, and nine banks ${ }^{15}$. The banking system holds $75 \%$ of the USD 1.5 billion total assets with the rest in security firms and insurance companies. All the banks are privately owned except for a mid-sized Malawi Savings Bank which is owned by the government. Again, the banking market constitutes five foreign-owned banks and Automated Teller Machines (ATMs) and branches concentrated in the urban centres of the country. Malawi is designated as one of the poorest countries in the world with about 14.5 million out of 20.4 million people (representing $71 \%$ of the total population) living in abject poverty ${ }^{16}$. The financial market or outlook of the country does not seem encouraging due to high levels of poverty with about 1.5 billion USD in total assets which is very low even by regional comparison. The high incidence of poverty in the country suggests that a majority of the population does not access financial institutions reflecting the deficient infrastructure and the perceived lack of sufficient demand for them. Mandiwa ${ }^{3}$ contends that banks have about 250, 000 customers, and with another 250, 000 customers using services of non-bank financial institutions, including micro-credit institutions. Mandiwa ${ }^{3}$ again asserts that the financial system of the country suffers from product variety, limited outreach, high costs and low productivity, leading to high spreads, and lack of critical mass. The COVID-19 has further impacted the already suffering financial sector of the country.

On 2nd April 2020, the country recorded its first three COVID-19 cases. The number of cases then increased moderately until end-May, when there was an acceleration in the recorded cases. By early-July, the active cases spiked and are estimated to increase further as local COVID-19 testing capabilities continue to be expanded with development partners' assistance including Global Fund, United Nations Children's Fund (UNICEF), Department for
International Development (DFID), among others ${ }^{17}$. To curb the further spread of the virus, the government instituted a partial country-wide lockdown on 4th April with only critical businesses, including financial institutions working in shifts and essential services continuing to function. All international flights were halted except for those evacuating Malawian citizens into the country and carrying important health supplies. Since then, a 14-days self-quarantine as per the guideline of the World Health Organisation has been in effect for Malawian citizens arriving in the country ${ }^{18}$. These measures amalgamated with global slowdown spillovers, economic disruption in adjoining countries and border closures have decelerated economic activities and caused a convulsive shock to the global economy, including the financial sector. The pandemic is as of now fundamentally exacerbating the financial outlook of Africa, Malawi inclusive. Growth is expected to crumple to a negative $1.6 \%$ and a fall in real per capita by $3.9 \%$, making 2020 the most exceedingly worst year since 1970 for economic growth on the continent ${ }^{19}$. Again, the poverty rate is expected to rise by $2 \%$ of the continent's population, with $26 \%$ falling below the poverty line and erasing effacing five years of poverty reduction progress.

In so doing, the reserve bank of Malawi, International Monetary Fund (IMF), World Bank, and other development/donor agencies meanwhile proactively intervened to calm the financial sector and show commitment to using all possible measures. The reserve bank reduced its domestic currency Liquidity Reserve Requirement (LRR) for financial institutions by 125 basis points to $3.75 \%{ }^{17}$. It also reduced its Lombard Rate by $50 \%$ to 0.2 percentage points which were above the policy rate ${ }^{17}$. Mobile money charges were temporarily waived by the government to motivate cashless transactions in these perilous times where social contact is highly discouraged. More so, in order to provide support to the banks, the Emergency Liquidity Assistance (ELA) framework was introduced to support the banks in the event of worsening liquidity conditions. However, these measures aimed at stabilizing the financial institutions of the country are 
threatened by plausibility that there would be a sharp rise in non-performing loans, from the already significant levels of $6.3 \%$ in December $2019^{20}$. Scales of business and borrowers across sectors will be affected, as falls in revenue and income suggest that they would be unable to meet their financial obligations. Private financial institutions also stand endangered to non-performance. For instance, DFIs would undergo stress due to lending to households with no assets and volatile income, and some may end up not sustaining creditworthiness. Most of these institutions at risk are those with interbank liabilities and short-term funding. Moreover, should recuperation not be quick, there is a danger of 'zombie' firms and banks ${ }^{19}$. This implies that they are adequately bankrupt, notwithstanding the liquidation is not solidified as a result of policy forbearance.

Furthermore, financial institutions buffer, comprising liquidity buffers and banks' capital, are estimated to counter risks to the financial system of the country. In worst-case scenarios, the gradual financial meltdown of the country due to the pandemic could result in the systemic folding up of the previously infinitesimal financial institutions in the country". Tyson ${ }^{19}$ puts it this way "such problems make a 'credit crunch' imminent, with sharp reductions in the hoarding of capital and liquidity and new lending. Even if there are policy measures such as reduced interest rates and capital ratios to address these issues, because of the weak financial system of the country, their effectiveness would be subject to financial institutions' risk appetite. Hugh Riddell, the World Bank Country Manager for Malawi, inclines that the government lacks the fiscal space to respond to such policy measures without assistance from development partners $^{21}$. This will imply that the financial sector will add to hitherto recessionary forces in the country.

\section{Why financial institutions matter before, during and after disasters}

In the recent years, there is a clear realization that governments cannot achieve sustainable growth by acting alone. Several studies have emphasized the critical role played by financial institutions in the development of nations ${ }^{22-24}$. Financial institutions include but not limited to central banks, retail and commercial banks, internet banks, credit unions, savings and loan associations, investment banks and companies, brokerage firms, insurance companies, mortgage companies ${ }^{25}$, among others. These financial institutions play significant roles in the development process, by mainly allocating resources to their maximum productive uses. More importantly, financial institutions aid economic agent trade, pool risk, hedge, raising investment, and economic growth ${ }^{26}$. They also provide commercial customers and consumers with different types of banking products and a wide range of services.

The significant role played by financial institutions is apparent during market booms, crises, and after the crisis. During normal periods, thus, before the crisis, financial institutions drive economic growth and economic development by engaging in various activities. They engage in activities such as the introduction of niche strategies, motivating financial sector, microfinance credit, development of support services, mopping up savings, trade facilitation programs, capital mobilization, managing risk in financial institutions, insurance, and financial services ${ }^{27}$, among others.

During the crisis, financial institutions curtail most of these financial activities ${ }^{27}$. Given that the state is heavily dependent on the financial sector, the state's fiscal problems can be exacerbated. Government policies during crises make it easier for people to obtain financial products and services from these entities. In many countries, government directives and passed legislations encourage or even compel financial institutions to relax interest rates, service charges, loan repayment ${ }^{28}$, among others. Also, the role of financial institutions in the aftermath of the crisis cannot be underemphasized. Financial institutions employ techniques such as a generally tighter relationship between banks and government, directed lending to governments by captive domestic savers like pension funds, and cross border flows of funds ${ }^{29}$. Alan M. Taylor argues that the best warning signals of financial crisis or recession are usually high, sustained rates of credit growth, referred to as credit booms, undertaken during and after crisis ${ }^{30}$.

The impact of Covid-19 transcends the health sector to all other sectors, including finance. According to the IMF, World Economic Outlook, April 2020, the global economy is projected to decline by $3 \%$ in real GDP for $2020^{31}$. Governments all over the globe are responding to financial and economic shocks by providing macro-financial, monetary, and fiscal stimuli ${ }^{32}$. Regulators in various countries are responding by easing regulatory requirements, interim non-classification of non-performing loans (NPLS), loan payment deferments, reducing interest rates, suspension of service charges, among others. These regulations are being extended with the continual extension of lockdown protocols. The need to cushion the effect of the Covid-19 on citizens and an uncertain political outlook continues to increase the systemic vulnerability of financial institutions. Experts argue that governments have priorities, citizens, over financial institutions, and those vulnerabilities in the financial markets and developing countries could cause a new financial crisis ${ }^{31}$.

The Government of India permitted financial institutions to allow further a moratorium for another three months on payment of instalments of term loans, credit card dues and interest on limits after the first directive ended on 31st May $2020^{33}$. Similarly, in many African countries such as Malawi, Kenya, Ghana, Nigeria, South Africa, Tanzania, among others, the governments continue to deploy financial boost mechanisms that could result in dire consequences given that most developing countries have made limited progress in achieving robust financial system as found in advanced countries ${ }^{17}$.

It is therefore important for governments in developing countries to priorities financial institutions as they would be the drivers of economic growth and development in the aftermath of the Covid-19 pandemic. Post-COVID-19 restructuring of financial institutions would be difficult in many developing countries as a result of less technical, institutional, and legal capacity for tasks such as asset resolution ${ }^{28}$. Also, the fraction of the financial institutions with insolvencies and bad assets are often larger ${ }^{26}$, and thus, 
fewer healthy institutions to take over weaker ones. Restructuring done in a wrong way can lead to credit crunches, insolvency, and recession of the financial sector as a whole.

\section{Policy Recommendations}

The Covid-19 pandemic and the concomitant observance of prescribed health safety protocols such as social distancing and movement restrictions have rendered massive shock to all sectors of the global economy including healthcare companies, travel, and hospitality purveyors, retailers, automakers, financial institutions, among others. Financial institutions in developing countries are already encountering a downstream impact of the Covid-19 pandemic, and there is the need for these countries to put in place robust measures to lead through the crisis. The fragile nature of the financial system in developing countries posts a gloomy picture of the aftermath of the pandemic, and there is the need to prepare for an impending potential financial crisis. This paper proposes the following recommendations for policymaking in developing countries:

Governments in developing countries must priorities the financial sector by monitoring development in the sector and provide liquidity assistance if need be. This will ensure that financial institutions are prepared and well-positioned to avert any potential financial crisis after Covid-19 has subsided. The Emergency Liquidity Assistance (ELA) framework introduced by the Malawian Government is a step in the right direction ${ }^{17}$. This assistance framework aims to support banks in the event of worsening liquidity conditions as well as provide support to banks on a case-bycase basis. There is need to encourage strategic management and planning approaches to help design short and long term measures that can revive and stabilise the financial sector.

In the short-run, governments in developing countries should continue to ease the impact of the pandemic on financial institutions with an extension of the targeted period for the enjoyment of reduced liquidity requirements and policy rates. This will support financial institutions to continue lending and providing various services to their customers as well as save weaker ones from collapsing. The reduction of domestic currency liquidity reserve requirement (LLR) by 125 basis points to 3.75 percent and Lombard Rate by 50 percent to 0.2 percentage points above the policy rate, in Malawi ${ }^{17}$, brought lots of relief to financial institutions in the country. Equally important, governments can invest more and acquire more stakes in financial intuitions so as to ensure they are financially stable and increase public ownership of financial institutions.

Financial institutions should scale-up digital and payment infrastructure and related channels to augment the shift from physical to digital. This will help prevent direct transfer of funds which usually ends in the wrong hands and double payment in some cases. The distribution of funds to citizens through digital means by financial institutions will boost the operations of these institutions and also prevent physical contact with citizens. Scaling-up digital checkout and advanced mobile infrastructures such as cards or contactless payment systems will better position digital banking and e- commerce markets in developing countries such as Malawi once the pandemic subsides.

Financial institutions must put in place measures to improve operational and service delivery excellence to enhance competitiveness. Financial institutions must draw lessons from the limits and constraints posed by the pandemic. This lesson draws must be informed by the need to conduct tests on sustaining remote work options or flexible schedules, adopting the right technology and infrastructure to support continuous service delivery without compromising the quality of service or client expectations. In Malawi, the Government and financial institutions must establish operational and service delivery infrastructure such as security or access through biometrics, voice-activated transactions, and contactless ATM transactions with authentication accomplished through mobile.

Government and financial institutions must anticipate ongoing business continuity and resilience requirements. This can be done by updating the existing playbook to ensure coverage of new limits and risk factors revealed by the Covid-19 crisis. Financial institutions must also prepare and test the right communication strategy for both employees and customers, identify and prioritize needs and wants necessary for continuous provision of services to customers as well as evaluating the economic implications of each decision and operating models. Financial institutions must frequently communicate with clients on new ways to comply with regulations, minimizing investment risks, and ongoing changes to product portfolios. This will help shore up the dwindling investor confidence in asset and wealth management of financial institutions. Lack of communication has adverse effects on investment and retiree plans.

\section{Conclusion}

There is little doubt that the COVID-19 pandemic will leave a negative mark in many economies. For developing countries, the effects will be further accelerated by the already weak economy, spill over from developed countries, lack of strong institutions and even worse unending corruption and poor policies. However, the transition can be less painful should governments with the support of development agencies help develop intelligent postpandemic recovery plans. These plans should address the deep rooted causes of vulnerability in developing countries as well as financial prudence, good governance and functional macro and micro economic strategies.

\section{References}

[1] Zhu N, Zhang D, Wang W, Li X, Yang B, Song J, Zhao X, Huang B, Shi W, Lu R, Niu P. A novel coronavirus from patients with pneumonia in China, 2019. New England Journal of Medicine.2020 Jan 24.

[2] 'The Global Economic Outlook during the COVID-19 Pandemic: A Changed World', available at https: //www.worldbank. org/en/news/feature/2020/06/08/the-global-economicoutlook-during-the-covid-19-pandemic-a-changedworld, last accessed on $10^{\text {th }}$ August 2020 
[3] Mandiwa M. Access to financial services in Malawi: policies and challenges. Ministry of Finance, Economic Planning and Development, Malawi.2014.

[4] 'Global Economic Effects of COVID-19', available at https: //fas. org/sgp/crs/row/R46270. pdf, last accessed on $10^{\text {th }}$ August 2020.

[5] Kharoubi C, Dolle T. Coronavirus and financial markets: Uncertainties and lessons from an unprecedented crisis. Managing a Post-Covid19 Era.2020 May: 220.

[6] Goodell JW. COVID-19 and finance: Agendas for future research. Finance Research Letters.2020 Apr 12: 101512.

[7] Whitelaw S, Mamas MA, Topol E, Van Spall HG. Applications of digital technology in COVID-19 pandemic planning and response. The Lancet Digital Health.2020 Jun 29.

[8] He Z, Nagel S, Song Z. Treasury inconvenience yields during the covid-19 crisis. National Bureau of Economic Research; 2020 Jun 18.

[9] Loayza NV, Pennings S. Macroeconomic policy in the time of COVID-19: A primer for developing countries.

[10] Zhang D, Hu M, Ji Q. Financial markets under the global pandemic of COVID-19. Finance Research Letters.2020 Apr 16: 101528.

[11] Nicola M, Alsafi Z, Sohrabi C, Kerwan A, Al-Jabir A, Iosifidis C, Agha M, Agha R. The socio-economic implications of the coronavirus pandemic (COVID19): A review. International journal of surgery (London, England).2020 Jun; 78: 185.

[12] 'Central banks a stabilising force in response to unprecedented crisis', available at https: //www.bis. org/press/p200630. htm, last assessed on $10^{\text {th }}$ August 2020.

[13] Didier T, Huneeus F, Larrain M, Schmukler SL. Financing Firms in Hibernation during the COVID-19 Pandemic.

[14] Baldwin R, Tomiura E. Thinking ahead about the trade impact of COVID-19. Economics in the Time of COVID-19.2020; 59.

[15] 'List of Banks in Malawi', available at https: //www.globalbankingandfinance. com/list-of-banks-inmalawi/, last accessed on $10^{\text {th }}$ August 2020.

[16] 'World Poverty Clock: Malawi', available at https: //worldpoverty. io/index. html, last accessed on $10^{\text {th }}$ August 2020.

[17] 'Policy Responses to COVID-19', available at https: //www.imf. org/en/Topics/imf-and-covid19/PolicyResponses-to-COVID-19, last accessed on $10^{\text {th }}$ August 2020.

[18] Legido-Quigley H, Asgari N, Teo YY, Leung GM, Oshitani H, Fukuda K, Cook AR, Hsu LY, Shibuya K, Heymann D. Are high-performing health systems resilient against the COVID-19 epidemic? The Lancet.2020 Mar 14; 395 (10227): 848-50.

[19] 'The impact of Covid-19 on Africa's banking system', available at https: //www.odi. org/blogs/17013-impactcovid-19-africa-s-banking-system, last accessed on $10^{\text {th }}$ August 2020.

[20] 'Malawi Non Performing Loans Ratio', available at https: //www.ceicdata. com/en/indicator/malawi/nonperforming-loans-ratio\#: $\quad$ : text= Malawi's\%20Non\%20Performing\%20Loans\%20Ratio,
$4.3 \% 20 \% 25 \% 20$ in $\% 20$ the $\% 20$ previous $\% 20$ quarter., last accessed on $10^{\text {th }}$ August 2020.

[21] 'New Economic Analysis for Malawi Forecasts Slow Growth Due to COVID-19', available at https: //www.worldbank. org/en/news/pressrelease/2020/07/24/new-economic-analysis-formalawi-forecasts-slow-growth-due-to-covid-19, last accessed on $10^{\text {th }}$ August 2020.

[22] Hall S, Foxon TJ, Bolton R. Financing the civic energy sector: How financial institutions affect ownership models in Germany and the United Kingdom. Energy Research \& Social Science.2016 Feb 1; 12: 5-15.

[23] Babb SL, Kentikelenis AE. International financial institutions as agents of neoliberalism. The SAGE handbook of neoliberalism.2018 Feb 26: 16-27.

[24] Lane PR, Milesi-Ferretti GM. The external wealth of nations revisited: international financial integration in the aftermath of the global financial crisis. IMF Economic Review.2018 Mar 1; 66 (1): 189-222.

[25] Cheng X, Degryse H. The impact of bank and nonbank financial institutions on local economic growth in China. Journal of Financial Services Research.2010 Jun 1; 37 (2-3): 179-99.

[26] Lettau M, Madhavan A. Exchange-traded funds 101 for economists. Journal of Economic Perspectives.2018 Feb; 32 (1): 135-54.

[27] Madura J. Financial markets \& institutions. Cengage learning; 2020 Jan 23.

[28] Ashraf BN. Economic impact of government interventions during the COVID-19 pandemic: International evidence from financial markets. Journal of Behavioral and Experimental Finance.2020 Jun 29: 100371.

[29] 'Understanding Financial Crises: Causes, Consequences, and Policy Responses', accessed at https: //www.imf. org/external/np/seminars/eng/2012/fincrises/pdf/ck. pdf, last accessed on $16^{\text {th }}$ August 2020.

[30] Taylor AM. External imbalances and financial crises. National Bureau of Economic Research; 2012 Dec 6.

[31] Rizwan MS, Ahmad G, Ashraf D. Systemic Risk: The Impact of COVID-19. Available at SSRN 3615161.2020 May 31.

[32] Elgin C, Basbug G, Yalaman A. Economic policy responses to a pandemic: Developing the COVID-19 economic stimulus index. Covid Economics.2020 Apr $10 ; 1$ (3): 40-53.

[33] 'Deferment of Loan: COVID-19', available at https: //shivalikbank. com/deferment-of-loan/, last accessed on $16^{\text {th }}$ August 2020. 